\title{
DISTANT READING OF THE METADATA OF THE DIGITIZED HUNGARIAN CHARM CORPUS
}

\section{Emese Ilyefalvi}

Assistant professor at the Department of Folkloristics at the Eötvös Loránd University, Budapest, Hungary and a research fellow at MTA-ELTE Lendület Historical Folkloristics Research Group

ilyefalvi.emese@btk.elte.hu

\begin{abstract}
Based on Éva Pócs' manual charm index an online database was created for Hungarian verbal charms within the East-West Research Group at the Institute of Ethnology, Hungarian Academy of Sciences (Budapest), between 2013 and 2018. The main goal was to create a multidimensional digital database. Digital text preparation would open the gates to new interpretations and analyses, which would bring us closer to understanding the compound and complex phenomena of charms. In the Digital Database of Hungarian Verbal Charms users can search by various metadata, like date and place of collection/recording, name of collector/scribe, informant, type of source, function of the charm, rites/gestures, language of the text, keywords etc. This paper focuses on how different new arrangements and distant reading of the corpora can reshape our knowledge about the Hungarian verbal charms.
\end{abstract}

Key-words: digital database, digital textology, computational folkloristics, folklore database, distant reading, Hungarian verbal charms, visualisation of metadata, verbal charms 
The first to call attention to the potential of computational research of largescale metadata in the humanities was the literary historian Franco Moretti with his method of distant reading. (Moretti 2007). Although computational analysis has a long history within folkloristics and the problematic of classifying collected data has long preoccupied folklorists, we can only speak of large-scale digitization from the 2010 s on, and therefore of large-scale digital folklore collections that truly require computational and digital, methods and assistance. ${ }^{1}$

According to Canadian digital humanists, Geoffrey Rockwell and Stefan Sinclair, large scale analyses do not interpret texts, rather they explain them. "Explaining is [...] about discovering the large-scale patterns of change in texts. It is epidemiology; it tracks symptoms, not causes". (Rockwell-Sinclair 2016: 116). Translated to cultural studies or philology this means that they do not wish to explore the meaning of individual texts or phenomena (as happens in the case of close reading) but wish to explain the symptoms. After presenting some of the milestones of computational folkloristics, my paper will call attention to some of the symptoms through the distant reading of the metadata of the Hungarian verbal charm database and will formulate some suggestions for treating the symptoms.

\section{BEFORE THE DIGITAL BOOM}

The unmanageable quantity of texts presented a problem in folkloristics already before the digital boom and folklorists appeared among the pioneers of digital humanities. Folklorist-musicologist Bertrand Harris Bronson at the University of California, Berkeley began to use rudimentary IBM 5081 punch cards for typologizing Child-ballads in the 1940s (Bronson 1949; Voigt 1971: 540), practically at the same time as Roberto Busa, who is often called the father of digital humanities (Rockwell-Sinclair 2016: 49). Following this early precursor, computational folkloristic research really gained momentum during the $1960 \mathrm{~s},{ }^{2}$ and although it may seem that interest flagged during the $1980 \mathrm{~s}$ and $90 \mathrm{~s}$, in fact computational folkloristics can be considered something continuous. ${ }^{3}$

The first research projects primarily were related to formalization, modelling, and taking off from these to typologization, as the potential of the computer was first and foremost in the assistance it could provide in classification. By then scholars of folk culture have long been struggling with "questions of storing, analyzing and comparing data, and when their data had become very 
numerous these tasks could only be accomplished by computers" wrote Vilmos Voigt at the beginning of the 1970s (Voigt 1971: 540-541).

Folklorists were not only relying on computers for their speed and the possibilities offered by them for organizing and classifying data but were also hoping that they would be able to assign individual texts and especially the motifs appearing in the texts to several categories. Already in 1968 Éva Pócs, for example, at the time of her first attempt to typologize Hungarian charms, was hoping that punch cards would prove to be a good solution for future typological problems (Pócs 1968: 277-278).

\section{DIGITAL DATABASE OF HUNGARIAN VERBAL CHARMS}

We published the test version of the Digital Database of Hungarian Verbal Charms in August 2018 with 1712 charm texts at the conclusion of the ERC project Vernacular Religion on the Boundary of Eastern and Western Christianity, Continuity, Changes and Interactions, ${ }^{4}$ under the European Union's Seventh Framework Program (FP7/2007-2013) /ERC grant agreement No 324214. Additionally our research group has digitally prepared 6037 texts. For the analyses of this paper, I have used the entire material that had been digitally prepared. The immediate precursor of the database is the two-volume collection of charms entitled Charms [Ráolvasások] that Éva Pócs and I published in 2014 (Ilyefalvi 2014; Pócs 2014). The two volumes: A, containing 19th-21st century texts, and B, comprising texts that survived in pre-19th century historical sources with their 1500 pages and nearly 3500 texts (and reference to further roughly $3000-3500$ variants) is one of the most voluminous textual publications of European charms research. ${ }^{5}$ In terms of its conceptualization it was a rather unique endeavour in that there is hardly any other collection of charms that attempts to bring together and publish the entire repertory of charms of a single nation/language from the earliest historical sources to the most recently collected folklore material. In the charms database we provided the following metadata to the individual records: type, function, ritual gesture, type of source, venue of collection/ collector, informant (name, sex, age, and further data if known), the language of the item, place of storage, reference to the original publication. 
Emese Ilyefalvi

\section{THE CORPUS IN THE LIGHT OF THE METADATA}

What can we conclude about this Hungarian digital charm corpus in the light of the metadata? What kind of symptoms can we observe? Thanks to digitization we can have a better understanding of the composition of the corpus than ever. ${ }^{6}$ Although the unevenness of the corpus was already known (namely, that compared to charms deriving from folklore collection we have few historical data), now we have a much more detailed picture of the extent and nature of these.

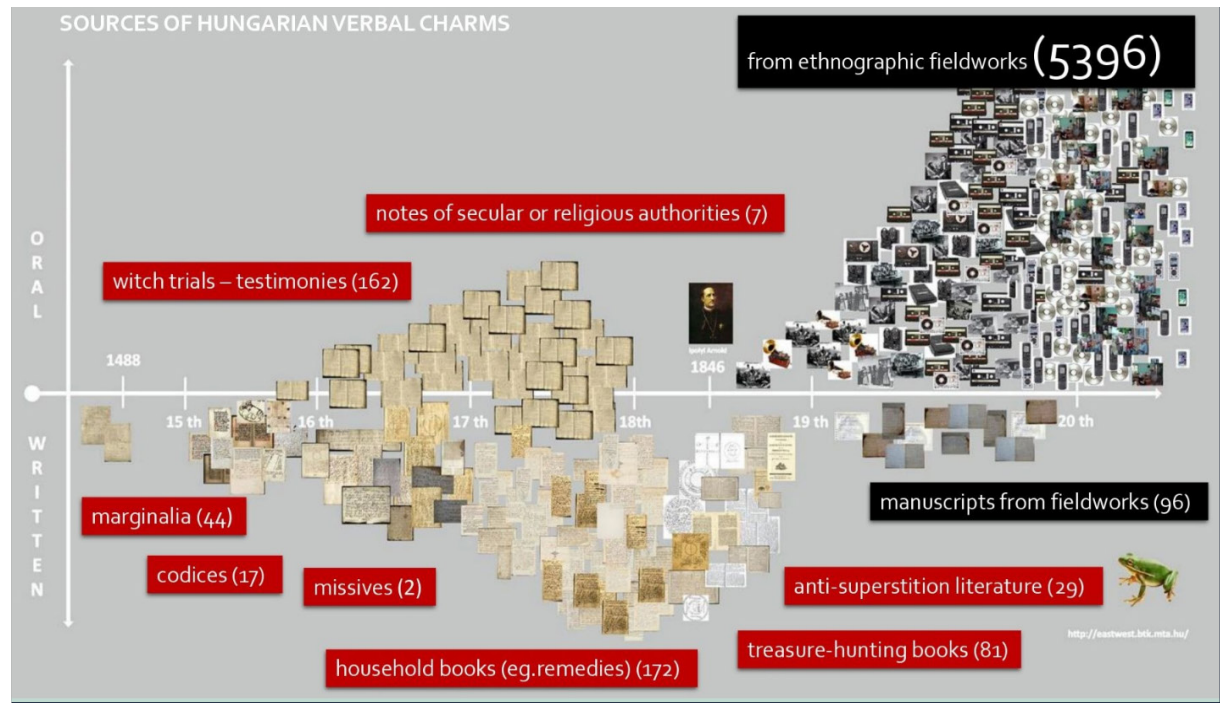

Figure 1: Infographic of the corpus of Hungarian charms drawn in Photoshop 
In Diagram 1 we can see the visualization of the corpus of Hungarian charms drawn in Photoshop. The timeline demonstrates the differences between the two kinds of tradition (oral and written), their relative proportions, the spread of the sources of the corpus in time, the variety of sources, and changes in collection techniques. In the digitally drawn infographics I highlighted the most important milestones of Hungarian charms research (the Bagonyai charms as the first data of the genre in 1488, Arnold Ipolyi as the first folklorist to collect and publish charm texts in 1846), and I tried to place the data deriving from witness accounts of witch trials in the border zone between oral and written sources. Although the infographics say a lot about the corpus, they do not reflect the real proportions and unevenness. In order to see these, we need to carry out computational analyses.

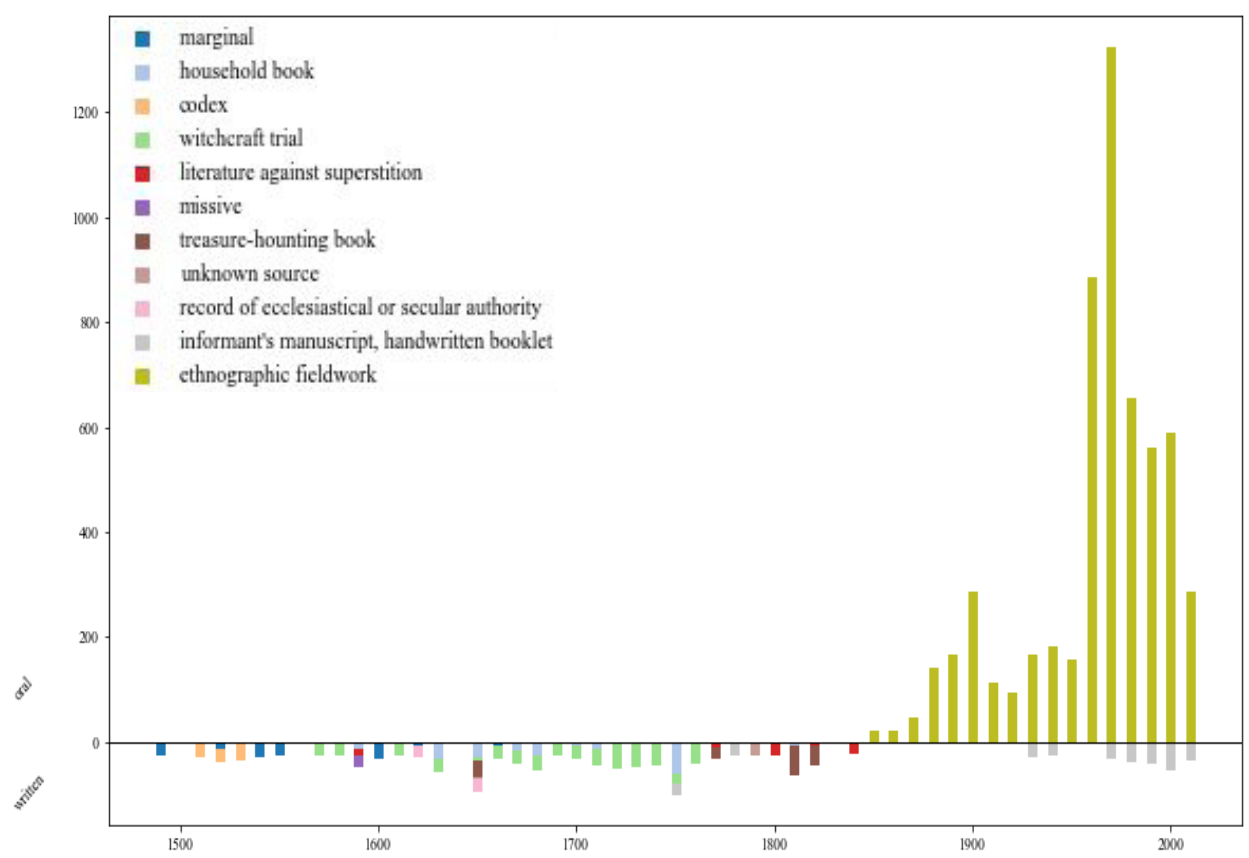

Figure 2: Distribution of the data of the charm corpus in time and according to the types of sources ${ }^{7}$ 
Emese Ilyefalvi

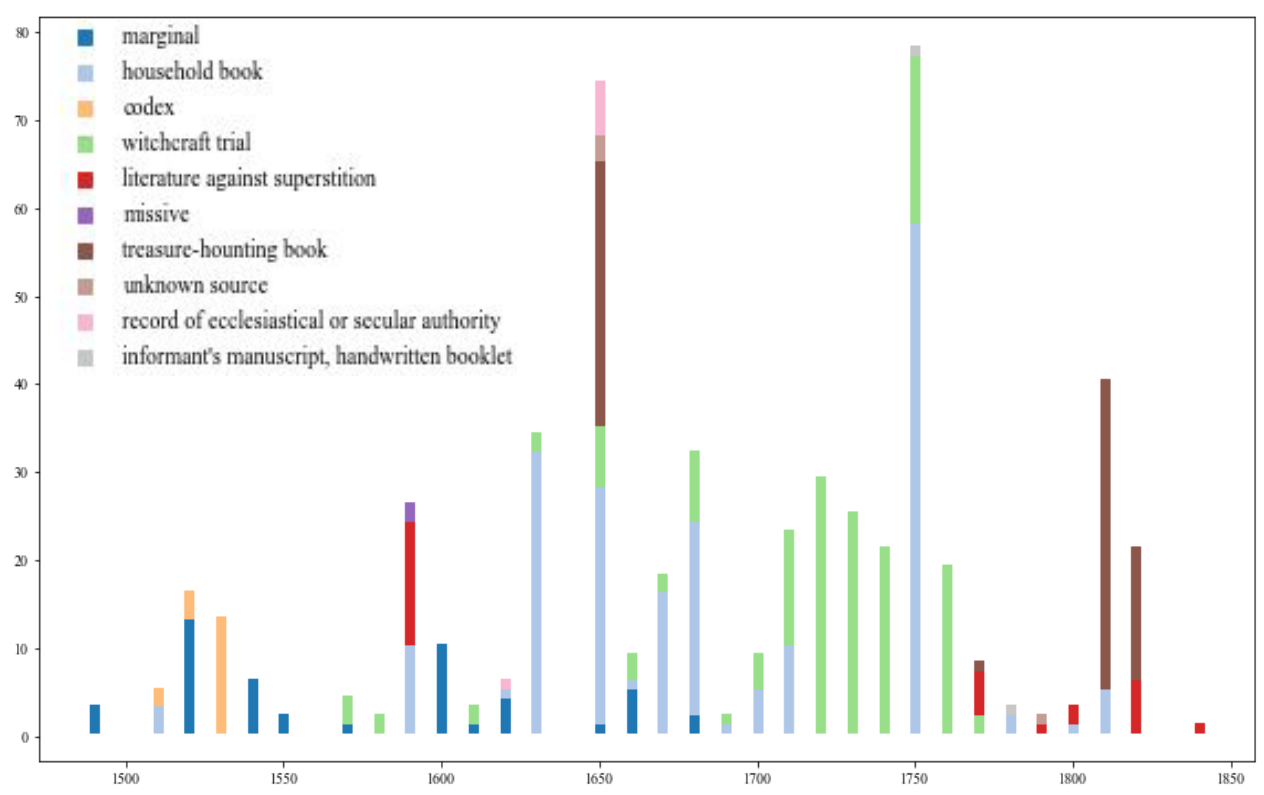

Figure 3: The distribution of pre-1851 charm texts in time and according to types of sources

According to the state of the database finalized on August 31, 2018, 82.11\% of the corpus is comprised of texts collected during the course of the 20th $-21 \mathrm{st}$ centuries. Examining the text corpus according to the types of sources the proportion of texts from folklore collections is even higher. Altogether $90.98 \%$ of the data derive from 19th -20 th and 21 st century folklore collecting. ${ }^{8}$

In the case of historical sources, the proportions demonstrate the arbitrariness and haphazardness of the exploration of the sources (Ilyefalvi 2014: 21-23). What is also remarkable is the almost complete absence of any evidence of the collection of manuscripts, i.e., of folk literacy. This lack is explained by the self-definition of folkloristics (as primarily researching orality) when it first emerged as a discipline. ${ }^{9}$

It is also instructive to examine how the data deriving from folklore (at present altogether 5476 items) are distributed over the 19th - 20th centuries. The graph below (Figure 4) shows the numerical values of folklore collections in 20-year blocks. 


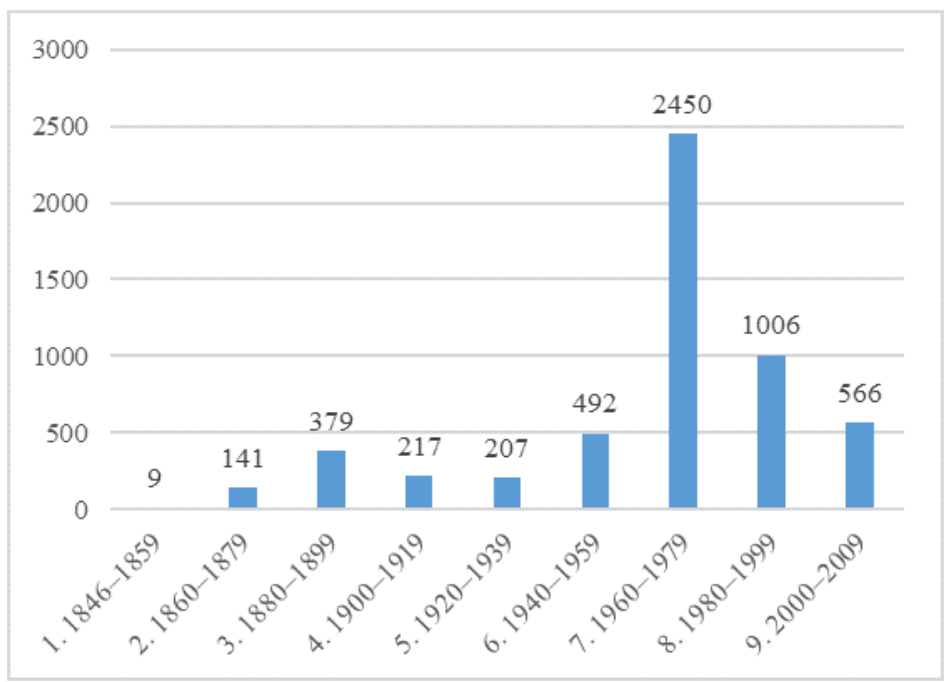

Figure 4: The distribution of the items of the charm corpus broken down into twenty-year blocks ${ }^{10}$

The amount of data in the period between 1960 and 1979 are exceptionally high, they comprise $45 \%$ of charms obtained through folklore collection, altogether 2450 data items. For those familiar with Hungarian folkloristics and the history of Hungarian charms research the above proportions are perhaps not surprising but they certainly call for explanation. In the course of data collecting activity associated with the creation of the Atlas of Hungarian Folk Culture (AHFC), the Topography of Hungarian Folk Beliefs (THFB) and the Atlas of Szolnok County Folk Culture (ASzFC), several questions related to practices of healing/harming with charms were included, thus thanks to these questionnaire surveys we have country-wide data for the phenomenon (Barabás 1958; Diószegi 1967; Pócs 2001a; 2001b; 2014: 42). At the same time, if we compile the data without those of the various Atlases, we shall still see that from the 1960s, but especially from the 1970s on, the collection of charms by folklorists intensified (Figure 5). 33\% of all folklore collection of charms derives from this period even without counting the results of the collecting activity carried out for these ethnographic atlases. This 'symptom' may be explained on the one hand by the fact that from the 1960s and 70s onwards, research on topics related to folk religiosity and folk beliefs was no longer prohibited by the Communist regime. On the other hand, this was the period 


\section{Emese Ilyefalvi}

when the activities of a few dedicated charms scholars began to flourish or came into full bloom (Pócs 2014: 34).

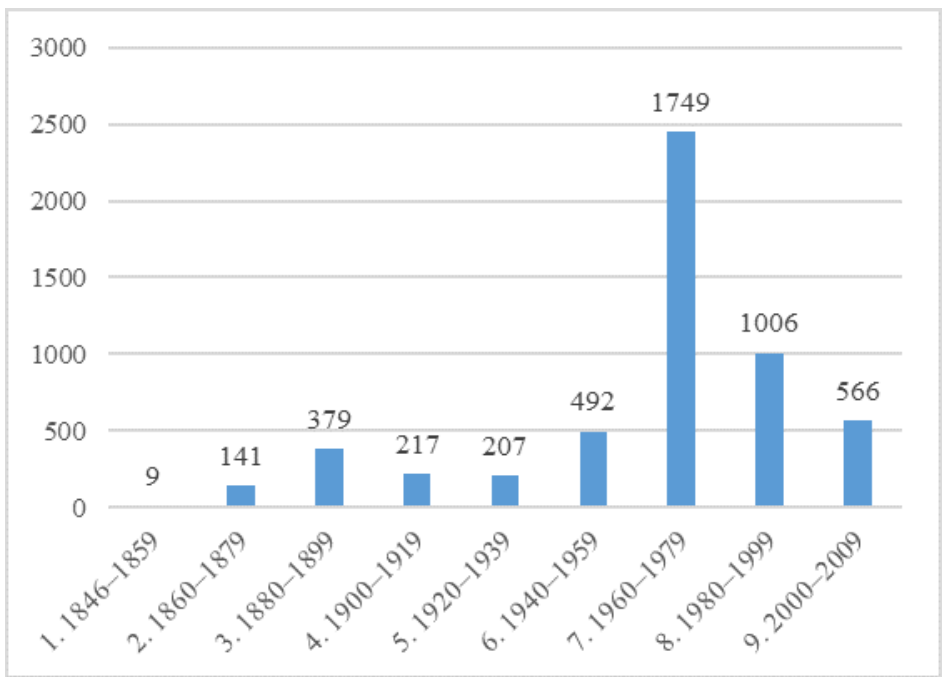

Figure 5: Distribution of the charm corpus without the data of the ethnographic atlases (AHFC, THFB, and ASzCFC)

In the course of digitally preparing the texts, we marked the rituals themselves and cases when speech acts (i.e. charms texts) were associated to them separately, therefore we can determine the proportion of descriptions of rituals to charms texts in the corpus. We may have had hunches and impressions about these earlier, however, asking this question and gaining a numerical answer to it is only made possible by digital data preparation. 


\begin{tabular}{|c|c|c|c|c|c|c|c|c|c|c|}
\hline & 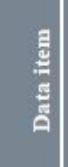 & 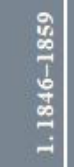 & 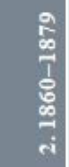 & 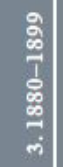 & 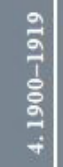 & 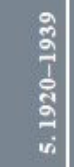 & $\begin{array}{l}\frac{0}{2} \\
\frac{1}{7} \\
\frac{1}{2} \\
\frac{2}{0} \\
0\end{array}$ & 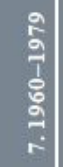 & $\begin{array}{l}\frac{a}{2} \\
\frac{0}{1} \\
\frac{\infty}{\infty} \\
\frac{\infty}{2}\end{array}$ & 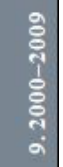 \\
\hline Full corpus & 5476 & 9 & 141 & 379 & 217 & 207 & 492 & 2450 & 1006 & 566 \\
\hline Texts & 5176 & 9 & 141 & 366 & 215 & 206 & 471 & 2313 & 931 & 526 \\
\hline Rites & 4270 & 9 & 120 & 370 & 156 & 177 & 363 & 1698 & 859 & 536 \\
\hline Texts/Data item & $95 \%$ & $100 \%$ & $100 \%$ & $97 \%$ & $99 \%$ & $100 \%$ & $96 \%$ & $94 \%$ & $93 \%$ & $93 \%$ \\
\hline Rites/Data item & $78 \%$ & $100 \%$ & $85 \%$ & $98 \%$ & $72 \%$ & $86 \%$ & $74 \%$ & $69 \%$ & $85 \%$ & $95 \%$ \\
\hline Collectors & 542 & 4 & 19 & 52 & 76 & 68 & 77 & 157 & 71 & 18 \\
\hline Collector/Data item & $9,9 \%$ & $44 \%$ & $13 \%$ & $14 \%$ & $35 \%$ & $33 \%$ & $16 \%$ & $6 \%$ & $7 \%$ & $3 \%$ \\
\hline
\end{tabular}

Figure 6: Numerical values for data on texts and rituals among the material deriving from folklore collecting

Figure 6 shows that $95 \%$ of charms are constituted by texts in the corpus, which supports the earlier insight of Hungarian charms studies that researchers of the genre primarily collected and published those charms that entailed concrete speech acts. When querying the data of the table we will also realize that during the 1960s and 1970s, the above mentioned 'heyday' of charms collection, collectors paid the least attention to recording the rites and gestures belonging to the texts or at least to publishing them. Between 1960 and 1979, rites are noted down in $69 \%$ of the data, which is a much lower rate than among all the other charms combined, and even when we compare it to all the other time intervals. This can most likely be attributed to collecting methodologies (e.g. the questionnaires of the atlases.) If we re-examine the question excluding the data from the three questionnaires, we still get the same result, i.e., that although without those data the number of descriptions of rituals is much higher between 1960 and 1979, but still, compared to all other time periods (with the exception of the period between 1900 and 1919) the period still has significantly fewer description of rites and gestures (Figure 7). 


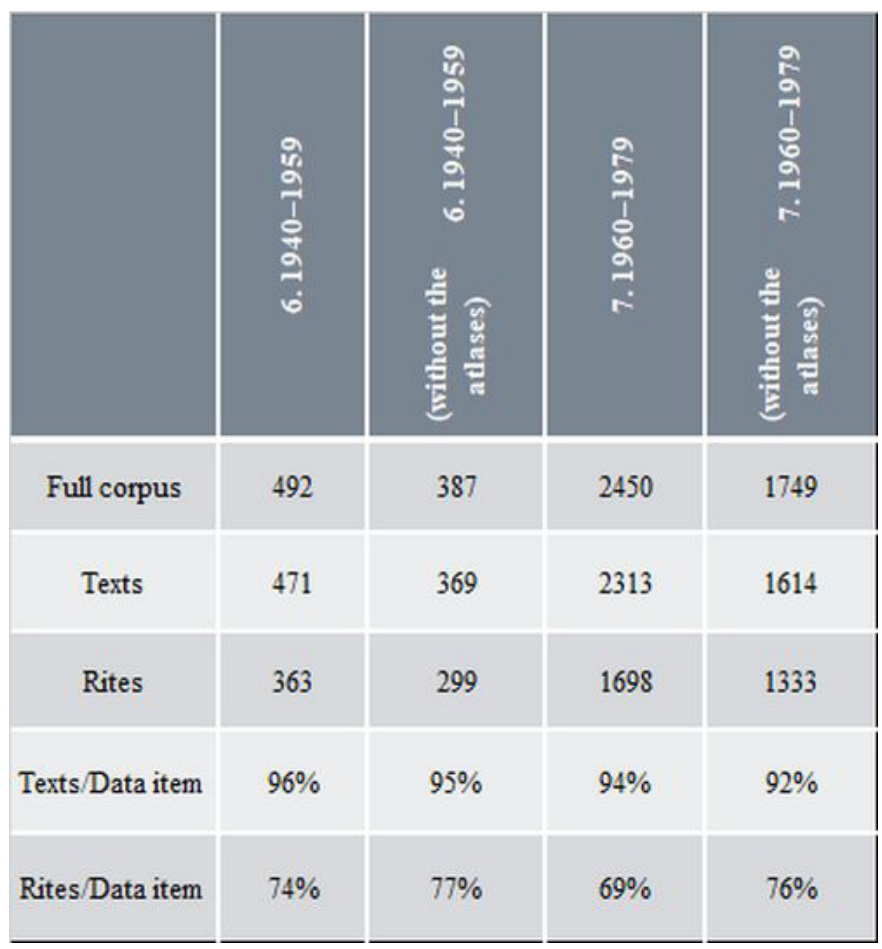

Figure 7: Numerical values for data on texts and rituals among the material deriving from folklore collecting without the data of the atlases (AHFC, THFB, and ASzCFC)

In the case of folklore corpora, it is important to know how many collectors the data comes from. The digital text corpus is the result of the collecting activity of 542 collectors. 


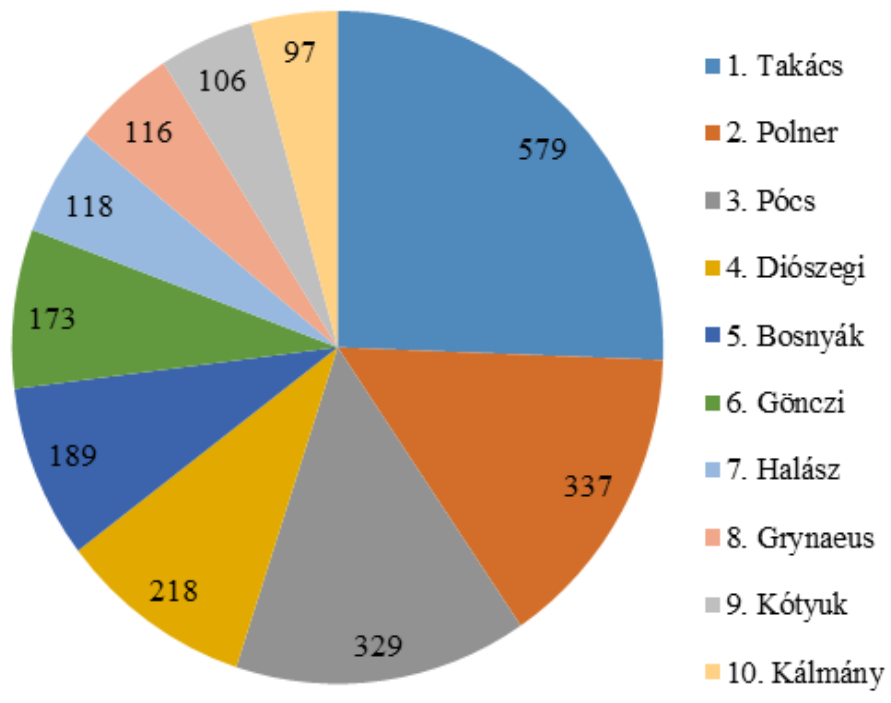

Figure 8: The ten researchers who collected the largest number of charms texts

The ten most prolific collectors can be seen on the pie chart (Figure 8). They collected $41.3 \%$ of all charms in the database, altogether 2262 texts. If we examine the proportions of the descriptions of rituals to speech acts, once again we will notice that between 1950 and 1973 Vilmos Diószegi and Éva Pócs who played a significant role in the large-scale folklore collections mentioned above, collected significantly fewer descriptions of rituals when compared to both other collectors and the totality of data. 


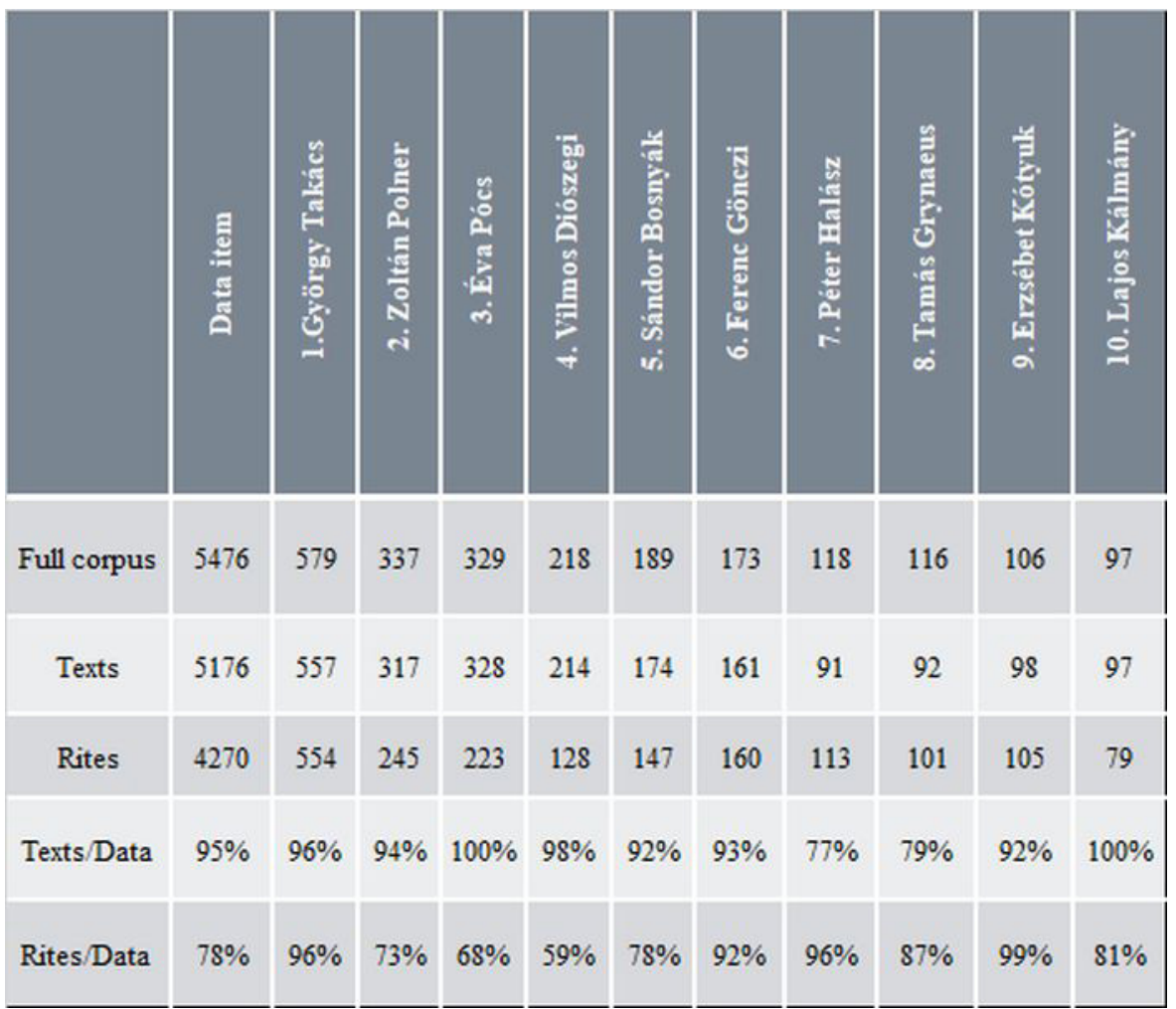

Figure 9: The number of texts and ritual descriptions collected by the ten most prolific collectors of charms

The corpus of György Takács whose collection activity stands out in terms of the quantity of texts he recorded. The database currently contains 579 texts (10.6\% of the totality) that he collected in the course of fieldwork in Csík, Valea Uzului, and Ghimeș over the past 30 years. We also have to thank him for the most recent data. That is to say, if we examine the last twenty years of the corpus (altogether 1258 texts between 1990 and 2009), 46\% of it has been collected by György Takács, but if we hone in on the last ten years, then 384 out of 566 texts, more than $50 \%$ of the total number in the database are there thanks to him. 
It also follows from the above that for the most recent period we only have data from areas beyond the borders of Hungary and within that the majority come from research among Hungarians in Romania. Between 2000 and 2009 we only have 7 charms from Hungary, 2 from Ukraine, while there are 555 from among Hungarians in Romania. We can also see the unevenness of regional distribution when looking at the number of data broken down by county: Harghita /Hargita County 331), Bacău/Bákó County (210), Cluj/Kolozs County (1), Mureș/Maros County (13).

Overviews that indicate the number of data per settlement are indispensable, since it is possible that we have a proportionately large amountof data from after 2000, but they may be coming from a single region.

\section{SYMPTOMS AND READINGS}

From the above figures the unevenness of the Hungarian charms database is clear. Given this, in keeping with the changed scale of computational research we cannot consider our data to be longitudinal, for example it is not suitable for the computational study of historical change for this very reason. ${ }^{11}$ Folklore databases can be large-scale in terms of their size, but they do not qualify as big data because they can never be complete datasets and for the most part, they have been prepared with particular research goals in mind. Folklorists have long been aware that folklore corpora, digital databases are artificially constructed. However, the enormous amount of digitized folklore material is not used only by folklorists. Because of the unevenness of the databases, we must make sure that we make the users aware of this in several different ways (e.g. in the introductory essays to the project, with the help of data visualization tools, etc.), so that they draw their conclusions from their analysis of the data with these characteristics in mind.

Good examples of this are the Dutch VolksverhalenBank and the Icelandic Sagnagrunnur. For example, gaining an overview of the Dutch folktale database corpus is helped by dynamic timelines operated by the users which makes it possible for them to see each hit in relation to the density of the collected data, too. 
Decennium timeline

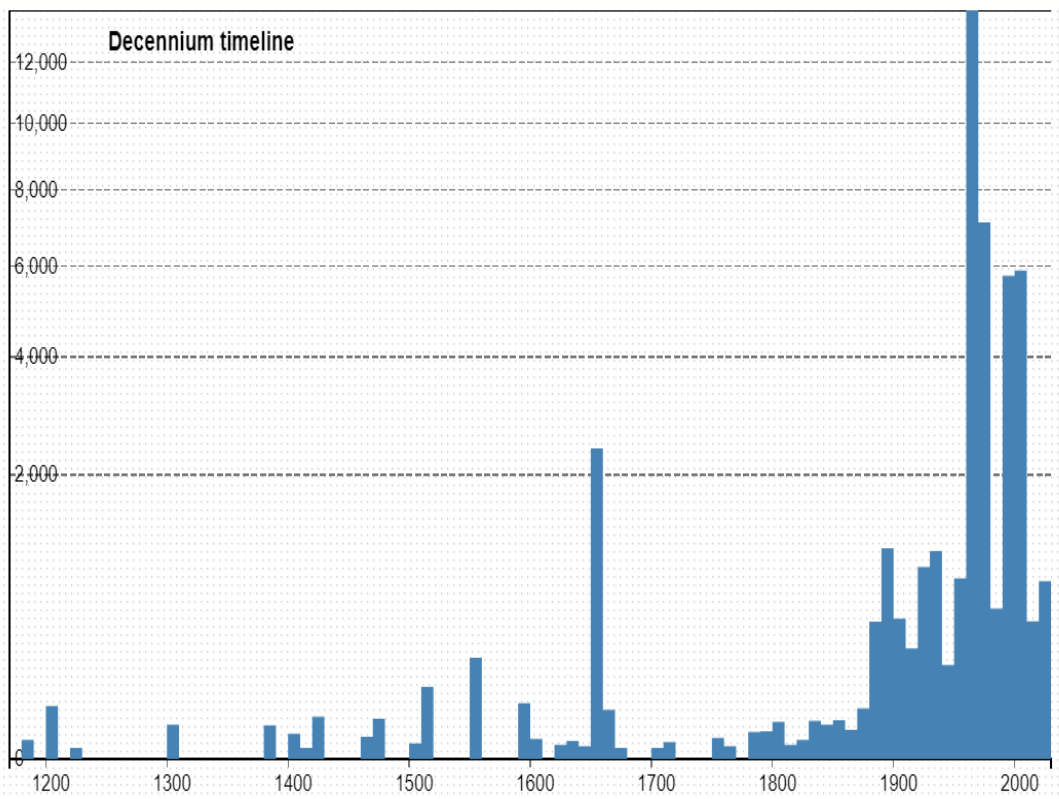

Figure 10: The dynamic timeline of Nederlandse VolksverhalenBank

The material of the Icelandic belief narrative database was connected with the mapping program called CartoDB in 2015, with its help viewing various layers of the data becomes possible. Blue indicates the homes of the informants (the size of the dots shows the number of informants from a given location proportionately), orange shows the number of texts collected at a given locale, while green conveys once again the number of informants at a given location, however, the size of the dots depends on the number of texts collected there. With the selection of the layers the user is free to choose from among the various modes of presentation. ${ }^{12}$ 


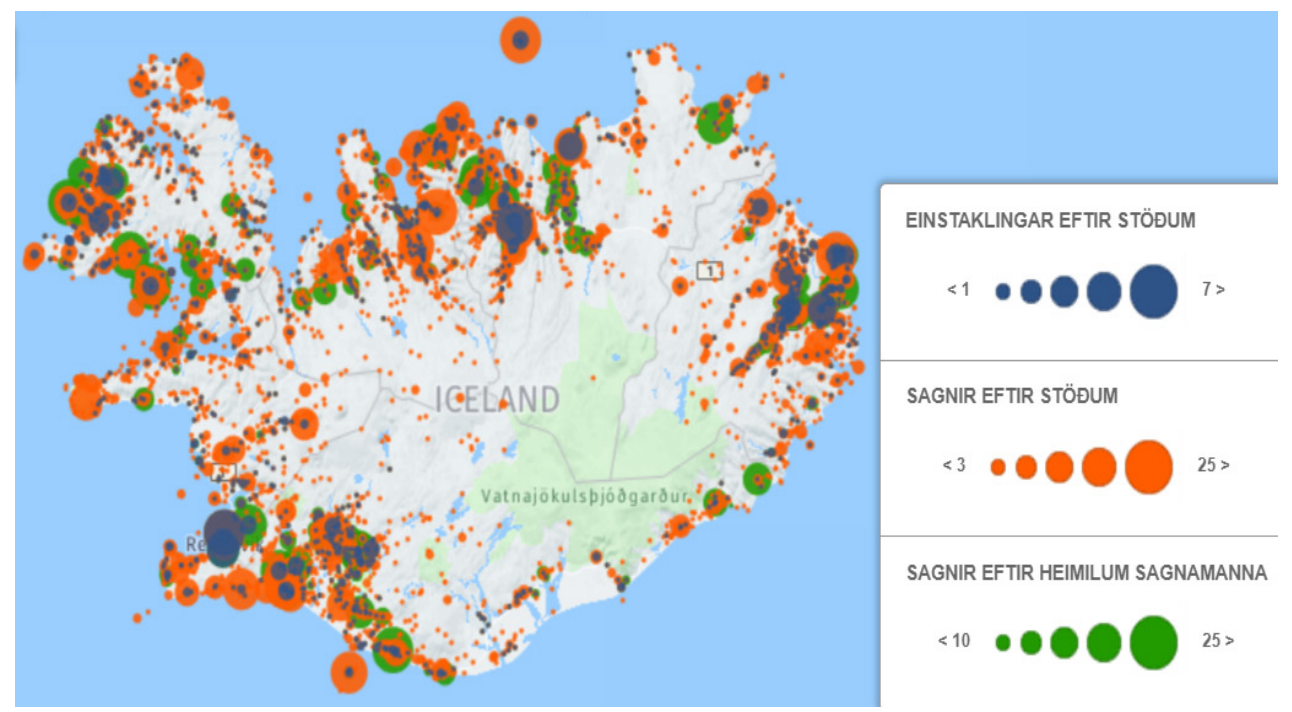

Figure 11: The data of Sagnagrunnur visualized with the CartoDB program, after choosing all the layers

Digital data and computational research hold the possibility of new kinds of errors since a badly prepared data item or a poorly chosen analytical method or tool can lead to erroneous conclusions. Although this was true of humanities research prior to the digital age as well, possibilities for error (in part due to the increased scale) have multiplied. According to folktale scholar Donald Haase, for this reason folklorists of the future will be obliged to master quantitative computational methods (Haase 2016: 79).

The unevenness and arbitrariness of the Hungarian digital charm corpus call our attention to the need to incorporate several dynamic visualizations and summaries into the user interface of the digital database to unequivocally remind researchers and users of these shortcomings. ${ }^{13}$

\section{ACKNOWLEDGEMENTS}

This research was supported by the ÚNKP-20-4 New National Excellence Program of the Ministry for Innovation and Technology from the source of the National Research, Development and Innovation Fund and the NRDI (National Research, Development and Innovation) Fund, project number 132535, project 


\section{Emese Ilyefalvi}

title: "Folk belief, vernacular religion, mentality, 16th-21st centuries: digital databases, encyclopedic summaries."

\section{NOTES}

${ }^{1}$ Cf. Abello \& Broadwell \& Tangherlini 2012; Tangherlini 2013, 2016; Kenna \& Maccarron \& Maccarron (eds.) 2017.

${ }^{2}$ Hungarian-born Thomas A. Sebeok for example studied the poetic and linguistic elements of various genres of Cheremis folklore, primarily folksongs (Sebeok 1965), the American anthropologist Benjamin N. Colby and his colleagues compared Kwakiutl, Egyptian Arabic, Inuit, Hindu and Chinese folktales with the help of computers (Colby-Collier-Postal 1963; Colby 1966). Under the direction of Marie-Louise Tenèze also during the 1960s French folklorists created a catalogue for French animal tales and created a system for digitally cataloguing folktales (Voigt 1971: 542). Canadian anthropologist Pierre Maranda modelled the organization of myths with the help of the computer (Maranda 1967). During the 1970s John Miles Foley analyzed the metrics of Beowulf with computer programs (Foley 1978).

${ }^{3}$ Cf., for example: Voigt-Preminger-Ládi-Darányi 1999. The first golden age of computational folkloristic and anthropological research can definitely be designated as the 1960s and 1970s, along with structuralism. See for example the edited volume primarily presenting North American research entitled The Use of Computer in Anthropology with an introduction by Dell Hymes (Hymes (ed.) 1965); or Vilmos Voigt's overviews regarding the question: Voigt 1971; 1976; 1981; 2007.

${ }^{4}$ See: http://eastwest.btk.mta.hu/.

${ }^{5}$ One of the largest recent text editions for example is Daiva Vaitkevičienè's Lithuanian charms collection, which publishes 1636 texts (Vaitkevičienè 2008).

${ }^{6}$ I am grateful to Péter G. Tóth for his help in preparing the tables for this study.

${ }^{7}$ Figures 2-3 were prepared by Márton Muntág, I am grateful for his assistance.

${ }^{8}$ The data collected from orality $(89.37 \%)$ and from handwritten booklets of the informants $(1.61 \%)$ add up to altogether $90.98 \%$.

${ }^{9}$ Thanks to the collecting efforts of György Takács, this part of the collection has been significantly enlarged in recent years, but we have not yet incorporated the data into the charm corpus. Cf., for example: Takács 2018.

${ }^{10}$ Because dates were often missing from the record in many cases, we had to supply the timeframe ourselves, as a result the twenty-year blocks of the graph show an approximate picture only. 
${ }^{11}$ Big data are such relatively complete datasets that did not come into being for the purpose of research. Cf. Rockwell \& Sinclair 2016: 124.

$12 \mathrm{http}: / /$ sagnagrunnur.com/2015/10/26/number-of-persons-and-legends-by-places/ (last consulted: 2019.03.21.).

${ }^{13}$ One of the best practices for dynamic research environment in folkloristics is the Dutch folktale database. On the user interface see: Muiser-Theune-de Jong-SminkTrieschnigg-Hiemstra-Meder 2017.

\section{REFERENCES}

Abello, James \& Broadwell, Peter \& Tangherlini, Timothy R. 2012. Computational Folkloristics. Communications of the ACM 55(7), pp. 60-70.

Barabás, Jenő 1958. A Magyar Néprajzi Atlasz kérdöive [The Questionnaire of the Atlas of Hungarian Folk Culture]. I-IV. Budapest: Magyar Tudományos Akadémia.

Bronson, Bertrand H. 1949. Mechanical Help in the Study of Folk Song. The Journal of American Folklore 62(244): 81-86.

Colby, Benjamin N. \& Collier, George A. \& Postal, Susan K. 1963. Comparison of Themes in Folktales by the General Inquirer System. The Journal of American Folklore, 76(302): 318-323.

Diószegi, Vilmos 1967. Az ,árpa” gyógyítása [Curing Sty]. In Lajos Szolnoky (ed.) Mutatvány a Magyar Néprajzi Atlasz anyagából [Examples from the Material of the Atlas of Hungarian Folk Culture]. (A Néprajzi Múzeum Füzetei 23.) Budapest: Néprajzi Múzeum, pp. 59-66.

Darányi, Sándor 1996. Formal aspects of natural belief systems, their evolution and mapping: A semiotic analysis. Semiotica 108(1-2): 45-63.

Dundes, Alan 1965. On Computers and Folk Tales. Western Folklore 24(3): 185-89.

Foley, John Miles 1978. A Computer Analysis of Metrical Patterns in Beowulf. Computers and the Humanities. Medieval Studies and the Computer 12(1/2): 71-80.

Haase, Donald 2016. Challenges of Folktale and Fairy-Tale Studies in the Twenty-First Century. Fabula: Zeitschrift für Erzählforschung, 57(1-2): 73-85.

Hymes, Dell (ed.) 1965. The Uses of Computers in Anthropology. The Hague: Mouton and Co.

Ilyefalvi, Emese 2014. Bevezető [Introduction]. In Emese Ilyefalvi (ed.) Ráolvasások. Gyüjtemény a történeti forrásokból (1488-1850) [Incantations. Collection from Historical Sources (1488-1850)]. (A magyar folklór szövegvilága 2/B) Budapest: Balassi Kiadó, pp. 11-37. 


\section{Emese Ilyefalvi}

Ilyefalvi, Emese (ed.) 2014. Ráolvasások. Gyüjtemény a történeti forrásokból (14881850) [Incantations. Collection from Historical Sources (1488-1850)]. (A magyar folklór szövegvilága 2/B) Budapest: Balassi Kiadó.

Kenna, Ralph and Maccarron, Máirín \& Maccarron, Pádraig (eds.) 2017. Maths Meets Myths: Quantitative Approaches to Ancient Narratives. (Understanding Complex Systems.) Cham: Springer International Publishing.

Maranda, Pierre 1967. Computers in the bush: analysis of Ge Mythology. In June Helm (ed.) Essays on the Verbal and Visual Arts: Proceeding of the 1966 Annual Spring Meeting of the American Ethnological Society. Seattle: Etats-Unis d'Amérique-University of Washington Press, pp. 77-83.

Moretti, Franco 2007. Graphs, Maps, Trees: Abstract Models for a Literary History. London: Verso.

Muiser, Iwe Everhardus Christiaan and Theune, Mariët; de Jong, Ruud; Smink, Nigel-Trieschnigg, Dolf; Hiemstra, Djoerd \& Meder, Theo 2017. Supporting the Exploration of Online Cultural Heritage Collections: The Case of the Dutch Folktale Database. Digital Humanities Quarterly 11(4). http://www.digitalhumanities.org/dhq/vol/11/4/000327/000327.html

Pócs, Éva 1968. A magyar ráolvasások müfaji és rendszerezési problémái [Generic and Classification Problems of Hungarian Incantations]. Népi kultúra-népi társadalom. [Folk Culture and Society] (A Magyar Tudományos Akadémia Néprajzi Kutatóintézetének évkönyve I.) Budapest: Akadémiai Kiadó, pp. 253-280.

Pócs, Éva 2001a. Újholddal kapcsolatos ráolvasások [New Moon Charms]. In László Szabó, Éva Gulyás, Zsolt Csalog (eds.) Szolnok (Jász-Nagykun-Szolnok) megye néprajzi atlasza (SzMNA) [Atlas of Szolnok County Folk Culture] II. 1. Szolnok: Jász-Nagykun-Szolnok Megyei Múzeumok Igazgatósága, pp. 138-141.

Pócs, Éva 2001b. Patkányküldés [Sending away Rats]. In László Szabó, Éva Gulyás, Zsolt Csalog (eds.) Szolnok (Jász-Nagykun-Szolnok) megye néprajzi atlasza (SzMNA) [Atlas of Szolnok County Folk Culture] II. 1. Szolnok: Jász-Nagykun-Szolnok Megyei Múzeumok Igazgatósága, pp. 142-147.

Pócs, Éva (ed). 2014. Ráolvasások. Gyüjtemény a legújabb korból 1851-2012 [Incantations. Collection from the Modern Age (1851-2012)]. (A magyar folklór szövegvilága 2/A) Budapest: Balassi Kiadó.

Rockwell, Geoffrey and Sinclair, Stéfan 2016. Hermeneutica. Computer-Assisted Interpretation in the Humanities. Cambridge, MA: The MIT Press.

Sebeok, A. Thomas 1965. The Computer as a Tool in Folklore Research. In Dell Hymes (ed.) The Uses of Computers in Anthropology. The Hague: Mouton and Co, pp. 255-272.

Takács, György 2018. „Az én lelkemmel elfújlak...” A magyarcsügési ráolvasófüzetek ["With my soul I blow you away" Charm Booklets from Magyarcsügés]. 
(Fontes Ethnologiae Hungaricae XIII.) Budapest-Pécs: L'Harmattan-PTE Néprajz-Kulturális Antropológia Tanszék.

Tangherlini, Timothy R. 2013. The Folklore Macroscope. Western Folklore 72(1): 7-27. Tangherlini, Timothy R. 2016. Big Folklore: A Special Issue on Computational Folkloristics. Journal of American Folklore, 129(511), pp. 5-13.

Vaitkevičienè, Daiva 2008. Lietuviu užkalbejjimai: gydymo formulés. Lithuanian Verbal Healing Charms. Vilnius: Lietuvių Literatūros ir Tautosakas Institùtas.

Voigt, Vilmos 1971. Számítógépes folklorisztika [Computational Folkloristics]. Természet világa: természettudományi közlöny 15/102(12): 540-543.

Voigt, Vilmos 1976. Means and Aims of Computer Folklore Research. In Ferenc Papp, György Szépe (eds.) Papers in Computational Linguistics. The Hague-Paris: Mouton, 549-553.

Voigt, Vilmos 1981. Computertechnik und -analyse. In Kurt Ranke (Hrsg.) Enzyklopädie des Märchens Handwörterbuch zur historischen und vergleichenden Erzählforschung 3. Berlin-New York: Walter de Gruyter, pp. 111-123.

Voigt, Vilmos 2007. Statistik. In Rolf Wilhelm Brednich, Kurt Ranke (Hrsg.) Enzyklopädie des Märchens Handwörterbuch zur historischen und vergleichenden Erzählforschung 12/3. Berlin-New York: Walter de Gruyter, pp. 1194-1200.

Voigt, Vilmos and Preminger, Michael; Ládi, László \& Darányi, Sándor 1999. Automated Motif Identification in Folklore Text. Folklore. An Electronic Journal of Folklore 12: 126-141.

\section{BIO}

Emese Ilyefalvi studied folkloristics, religious studies and philology at Eötvös Loránd University, Budapest. She worked from 2013 to 2018 as a junior research fellow in the "East-West" Research Project ("Vernacular religion on the boundary of Eastern and Western Christianity: continuity, changes and interactions" ERC project No 324214). Within the framework of this project, she published a new Hungarian charm collection in 2014 co-authored with Éva Pócs and the Digital Database of Hungarian Verbal Charms in 2018. (See: http://raolvasasok.boszorkanykorok.hu/) She finished her PhD Thesis in 2019 about the theoretical, methodological and technical questions of computational folkloristics. She published several articles in Hungarian and international journals (Ethnographia, Replika, Incantatio) on these topics. She was a visiting scholar in Vienna (Collegium Hungaricum Wien), in Amsterdam (University of Amsterdam) and in Edmonton (University of Alberta, Wirth Institute for 
Emese Ilyefalvi

Aus $\neg$ trian and Central European Studies). Since 2013, she has been giving lectures and seminars related to her research at Eötvös Loránd University and the University of Pécs. At present, she is an assistant professor at the Department of Folkloristics (Eötvös Loránd University, Budapest, Hungary) and a research fellow at MTA-ELTE Lendület Historical Folkloristics Research Group.

ORCID: https://orcid.org/0000-0001-6677-5843 